\title{
GAMBARAN SEXUAL COMPLIANCE PADA REMAJA PEREMPUAN YANG MELAKUKAN PERILAKU SEKSUAL PRANIKAH
}

\author{
Uun Yosie Tigeryani
}

uunyosietigeryani@gmail.com

Fakultas Psikologi Universitas Katolik Widya Mandala Surabaya

\begin{abstract}
Abstrak
Penelitian mengenai sexual compliance masih jarang dilakukan di Indonesia. Penelitian mengenai sexual compliance juga kerap dilakukan dengan metode penelitian kuantitatif, sehingga hasil yang ditemukan berupa data persentase yang menjelaskan gambaran permukaan sexual compliance. Penelitian ini dilakukan mengeksplorasi secara mendalam gambaran sexual compliance pada perempuan yang melakukan perilaku seksual pranikah. Penelitian ini dilakukan dengan metode kualitatif fenomenologis dengan teknik analisis data inductive thematic analysis. Partisipan dalam penelitian ini adalah dua orang remaja perempuan yang pernah melakukan aktivitas seksual yang tidak diinginkan. Hasil dari penelitian ini berupa tema-tema yaitu mengenai perilaku seksual pranikah, tema sexual compliance, tema pemaknaan partisipan terhadap sexual compliance, serta tema mengenai kondisi partisipan saat ini.
\end{abstract}

Kata kunci: Sexual compliance, Perilaku seksual pranikah

\begin{abstract}
Study about sexual compliance is still rarely done in Indonesia. Study about sexual compliance is also often done with quantitative research methods, so that the results of the study are data percentages that describe the surface of sexual compliance. This study aims to explore sexual compliance in-depth in women who engaged in premarital sexual behavior. This study is a qualitative study with a phenomenological research method. The analysis technique of this study is an inductive thematic analysis. The subjects of this study are two teenage girls who engage in unwanted sexual activity. The results of this study are in the form of themes, which are about premarital sexual behavior, sexual compliance, meaning towards sexual compliance experience and about current condition of the subjects.
\end{abstract}

Keywords: Sexual compliance, Premarital sexual behavior

\section{Pendahuluan}

Sexual Compliance mengacu pada situasi dimana seseorang secara bebas setuju untuk berhubungan seks tanpa benarbenar menginginkannya. Perilaku sexual compliance lebih sering dilakukan oleh perempuan daripada laki-laki. Menurut Kristanti dan Poerwandari (2018) dalam artikel jurnal Psychological Research on Urban Society dengan judul Premarital Sexual Compliance among Urban Indonesian Women menyatakan bahwa terdapat korelasi signifikan antara usia dengan perilaku compliance dalam berhubungan seksual, yaitu usia 25 tahun ke bawah menunjukkan perilaku compliance dalam berhubungan seksual lebih tinggi dibanding usia 25 tahun ke atas. Perilaku sexual compliance sendiri juga memiliki dampak negatif, baik dari sisi psikologis maupun fisik. Dampak psikologis dari perilaku sexual compliance merupakan munculnya perasaan bersalah, takut, bingung, menyesal, dan malu (Kristanti dan 
Poerwandari, 2018). Dampak fisik yang dapat timbul melalui perilaku sexual compliance salah satunya adalah luka pada vagina karena proses bersenggama tanpa proses lubrikasi pada vagina, maupun proses lubrikasi yang kurang (SegarraEchebarria, Fernandez-Perez, GraciaMoncho, \& Delarze-Carillo, 2015). Dampak fisik lain perilaku sexual compliance selain pada saat kondisi intercourse adalah tertular penyakit kelamin seperti gonorhea, herpes genital dan sifilis melalui seks oral.

Penelitian-penelitian mengenai sexual compliance kerap dilakukan dengan metode penelitian kuantitatif, sehingga data yang dihasilkan merupakan data persentase mengenai gambaran permukaan sexual compliance. Penelitian mengenai sexual compliance yang dilakukan di Indonesia merupakan penelitian kuantitatif, sehingga tidak menggambarkan secara mendalam mengenai sexual compliance. Berdasarkan hal tersebut, maka dilakukan penelitian mengenai "Gambaran Sexual Compliance pada Perempuan yang Melakukan Perilaku Seksual Pranikah", dengan tujuan untuk memberikan gambaran mengenai sexual compliance secara mendalam yang dialami oleh perempuan yang melakukan perilaku seksual pranikah.

Masa remaja merupakan periode transisi perkembangan di antara masa anakanak dengan masa dewasa. Perkembangan yang terjadi pada masa ini meliputi perkembangan pada biologis, kognitif dan sosioemosional. Masa remaja dimulai dari rentang usia 10-13 tahun dan berakhir pada usia kira-kira 18-22 tahun (Santrock, 2011). Merujuk pada teori yang diungkapkan oleh Erik Erikson, masa remaja ditandai dengan adanya kecenderungan identity $v s$ identity confusion. Pada masa ini, remaja dihadapkan untuk memutuskan siapa diri mereka dan apa yang akan mereka lakukan untuk hidup mereka, sehingga remaja mulai mengeksplorasi apa yang menjadi ketertarikan mereka. Havighurst (dalam Hurlock, 2004) menyatakan tugas perkembangan remaja antara lain adalah menerima kondisi fisik dan menggunakan tubuhnya secara efektif, mempersiapkan perkawinan dan hidup berkeluarga, dan mencapai hubungan yang baru dan semakin matang dengan teman sebaya baik laki-laki maupun perempuan. Periode ini juga ditandai dengan adanya hubungan spesial dengan lawan jenis yang menunjukkan kedekatan atau kelekatan satu sama lain yang biasa disebut dengan istilah "pacaran".

Pemaparan teori di atas menggambarkan masa remaja sebagai masa-masa pencarian jati diri dan proses menuju kematangan yang terdapat berbagai proses kompleks di dalamnya. Proses kompleks tersebut salah satunya adalah ketertarikan dengan lawan jenis. Salah satu bentuk ketertarikan dengan lawan jenis adalah dengan berpacaran. Berdasarkan penelitian yang dilakukan oleh Setiawan dan Nurhidayah (2008) mengenai pengaruh pacaran terhadap perilaku seks pranikah, menyatakan bahwa terdapat hubungan positif yang signifikan antara pacaran dengan perilaku seksual pranikah. Penelitian ini menyatakan bahwa hubungan positif berarti pacaran yang dilakukan remaja akan semakin mengarah pada perilaku atau hubungan seksual pranikah. Hasil penelitian ini menunjukkan bahwa remaja yang berpacaran mempunyai peluang yang cukup tinggi terhadap aktivitas perilaku seksual pranikah.

Perilaku seksual pranikah adalah segala tingkah laku yang didorong oleh hasrat seksual yang dilakukan oleh dua orang, pria dan wanita di luar perkawinan yang sah (Sarwono, 2005). Faktor-faktor yang mempengaruhi perilaku seks pranikah adalah pengetahuan, meningkatnya libido seksual, media informasi, norma agama, orang tua, dan pergaulan yang semakin bebas. Perilaku seksual terdiri dari beberapa tahap. Menurut Sarwono (2011) bentukbentuk perilaku seksual dimulai dari perasaan tertarik hingga tingkah laku berkencan, bercumbu, sampai bersenggama (sexual intercourse). Hasil preliminari dilakukan pada perempuan yang melakukan 
hubungan seks pranikah, partisipan X (20 tahun) menyatakan bahwa ia pertama kali melakukan perilaku seksual pada saat duduk di bangku SMP. Bentuk perilaku seksual yang pertama kali ia lakukan adalah berciuman (kissing). Menurut pernyataan partisipan $\mathrm{X}$, setelah ciuman pertama pasangannya kerap meminta hubungan seksual yang lebih seperti ciuman di leher (necking), dan meraba alat kelamin (groping). Partisipan X menyatakan pasangannya sering mengajak menonton di bioskop, namun ketika film diputar, pasangan partisipan meminta partisipan untuk melakukan hubungan seksual seperti berciuman, meraba alat kelamin, dan melakukan seks oral di dalam bioskop. Partisipan X juga menyatakan hampir selalu memenuhi keinginan pasangannya untuk melakukan hubungan seksual walaupun ia tidak sedang menginginkan hal tersebut.

Berdasarkan preliminari yang dilakukan, partisipan melakukan aktivitas seksual sebelum proses pernikahan yang sah, bahkan partisipan menyatakan bahwa ia menyetujui aktivitas seksual tersebut walaupun ia tidak sedang menginginkan aktivitas tersebut. Beberapa studi menunjukkan bahwa wanita lebih sering menyetujui aktivitas seksual karena mereka merasa harus melakukannya walaupun tanpa paksaan, hal ini juga lebih sering muncul pada perempuan daripada pria (Impett \& Peplau, 2002; Katz \& Tirone, 2009; O'Sullivan \& Allgeier, 1998; Viscione, 2015). Wanita seringkali merasa bahwa ia harus setuju melakukan hubungan seksual untuk memuaskan kebutuhan pasangannya, walaupun tanpa tekanan atau ancaman dari pasangan,. Hal ini disebut perilaku compliance dalam berhubungan seksual (sexual compliance; French \& Neville, 2016; O’Sullivan \& Allgeier, 1998). Sebutan ini pertama kali dikemukakan oleh O'Sullivan dan Allgeier (1998), yang menyebut sexual compliance sebagai "consensual participation in unwanted sexual activity", atau "persetujuan untuk berpartisipasi dalam aktivitas seksual yang tidak diinginkan".
Sexual Compliance mengacu pada situasi dimana seseorang secara bebas setuju untuk berhubungan seks tanpa benar-benar menginginkannya, selain itu juga berpurapura bergairah atau tertarik, bahkan tanpa tekanan yang berlebihan untuk melakukannya.

Perempuan yang terlibat dalam sexual compliance berpotensi mengalami emosi atau perasaan negatif maupun konsekuensi fisik. Maass (2006) menyatakan bahwa perilaku compliance dalam berhubungan seksual yang timbul dari perasaan romantis di tahap awal hubungan dapat membuat perempuan merasa seperti telah berhasil memenuhi kebutuhan pasangannya, akan tetapi semakin berjalannya hubungan tersebut, perempuan tersebut akan merasa tidak nyaman karena tidak memiliki peran yang setara dalam hubungan mereka. Dampak psikologis lain dari perilaku sexual compliance merupakan munculnya perasaan bersalah, takut, bingung, menyesal, dan malu (Kristanti dan Poerwandari, 2018). Adapun konsekuensi fisik yang dapat terjadi pada perempuan adalah luka pada vagina karena proses bersenggama tanpa proses lubrikasi pada vagina, maupun proses lubrikasi yang kurang (Segarra-Echebarria, FernandezPerez, Gracia-Moncho, \& Delarze-Carillo, 2015). Dampak fisik lain perilaku sexual compliance selain pada saat kondisi intercourse adalah tertular penyakit kelamin seperti gonorhea, herpes genital dan sifilis melalui seks oral.

Berdasarkan artikel jurnal Psychological Research on Urban Society dengan judul Premarital Sexual Compliance among Urban Indonesian Women oleh Kristanti dan Poerwandari (2018), menyatakan bahwa 30,75\% dari 1.444 sampel penelitian pernah berpartisipasi sekali atau lebih dalam aktivitas seksual yang tidak ia inginkan. Artikel jurnal tersebut juga menyatakan bahwa terdapat korelasi signifikan antara usia dengan perilaku compliance dalam berhubungan seksual, yaitu usia 25 tahun ke bawah menunjukkan perilaku compliance 
dalam berhubungan seksual lebih tinggi dibanding usia 25 tahun ke atas. Adapun aktivitas seksual yang paling sering dilakukan adalah memberikan seks oral $(21,1 \%)$, seks anal $(19,4 \%)$, bersenggama $(18,2 \%)$, meraba alat kelamin $(14,2 \%)$, dan menerima seks oral (14\%). Selain itu alasan partisipan menyetujui aktivitas seksual yang tidak ia inginkan adalah menghindari konflik, ingin diterima pasangan, tidak ingin melukai perasaan pasangan, tidak ingin membuat pasangan merasa ditolak, mencegah pasangan kehilangan ketertarikan pada mereka, dan ingin meningkatkan intimasi/keintiman. Hal lain dalam artikel jurnal ini adalah konsekuensi emosional yang dirasakan setelah melakukan aktivitas seksual yang tidak diinginkan, adapun hasilnya adalah emosi positif, emosi negatif, dan emosi berlawanan. Hal ini dijelaskan lagi, dalam emosi positif terdapat perasaan dicintai $(58,1 \%)$, senang $(46 \%)$, romantis $(45,8 \%)$, dan puas (46\%). Selain itu dalam emosi negatif terdapat perasaan bersalah $(58,1 \%)$, takut $(42,2 \%)$, menyesal $(41,4 \%)$, malu $(39,4 \%)$, serta bingung $(38,1 \%)$. Adapun emosi berlawanan adalah partisipan yang menjawab emosi positif dan emosi negatif bersamaan. Terdapat $63,34 \%$ partisipan yang merasakan emosi berlawanan ini. Di satu sisi mereka merasakan emosi positif, namun di sisi lain mereka juga merasakan emosi negatif.

Artikel dalam Journal of Personality and Individual Differences dengan judul Borderline Personality Disorder Traits and Sexual Compliance: A Fear of Abandonment Manipulation oleh Wilis dan Gray (2017), menyatakan terdapat korelasi positif yang signifikan antara kecenderungan gangguan kepribadian borderline dengan perilaku sexual compliance. Ketakutan akan ditinggalkan merupakan salah satu ciri utama gangguan kepribadian borderline, studi ini menyatakan hasil bahwa ketika perempuan dengan kecenderungan gangguan kepribadian borderline dihadapkan dengan potensi ditinggalkan oleh pasangan, maka perempuan tersebut akan melakukan sexual compliance kepada pasangannya. Hal ini juga dapat meningkatkan perasaan stress dan ketidakpuasan dalam hubungan.

Preliminari studi lain berdasarkan artikel dalam Journal of Sex Research dengan judul Sexual Compliance: Gender, Motivational, and Relationship Perspective yang dilakukan oleh Impett dan Peplau (2003), menyatakan bahwa baik pria maupun wanita dapat menyetujui aktivitas seksual yang tidak mereka inginkan, namun wanita lebih sering melakukannya atau menjadi "compliant partner". Penelitian ini menyatakan terdapat $65 \%$ wanita yang mengaku pernah menyetujui melakukan aktivitas seksual walaupun mereka tidak menginginkannya, namun hanya terdapat $40 \%$ pria yang menjawab hal tersebut. Pada penelitian ini terdapat partisipan mahasiswa yang sedang berpacaran, yang memberikan hasil $50 \%$ wanita dan $26 \%$ pria menyetujui melakukan aktivitas seksual yang tidak diinginkan dengan pasangannya setidaknya sekali dalam dua minggu.

Berdasarkan artikel-artikel jurnal yang dipaparkan, dapat dilihat bahwa sexual compliance adalah sebuah perilaku dimana individu menyetujui aktivitas seksual yang tidak mereka inginkan. Perilaku ini dapat dilakukan baik oleh pria maupun wanita, walaupun menurut hasil penelitian di atas dikatakan bahwa wanita lebih sering melakukan sexual compliance dibandingkan pria. Alasan yang paling sering diungkapkan terkait mengapa individu mau melakukan aktivitas seksual yang tidak mereka inginkan adalah untuk meningkatkan keintiman dalam hubungan, untuk memberi kesan pada pasangan (tidak ingin pasangan merasa ditolak, dilukai), serta untuk merasa dapat menarik bagi pasangan. Hal ini jelas tidak sesuai dengan salah satu hal yang harus diperhatikan dalam berhubungan seksual yaitu keseimbangan kedudukan seksual. Dalam perilaku sexual compliance terdapat tingkatan dalam kedudukan seksual tersebut, adapun orang yang rela melakukan hubungan seksual yang tidak ia inginkan 
berada di bawah kedudukan orang yang meminta melakukan hubungan seksual. Hal ini tentunya akan mempengaruhi kondisi seseorang baik fisik maupun psikologis. Dampak psikologis yang negatif dari perilaku sexual compliance merupakan perasaan marah, bingung, takut, menyesal, malu bahkan stress. Dampak fisik perilaku sexual compliance yang dilakukan oleh wanita pada saat intercourse adalah luka pada vagina karena proses lubrikasi yang kurang dan rentan tertular penyakit kelamin seperti gonorhea, herpes genital dan sifilis yang dapat menular melalui seks oral.

Penelitian-penelitian mengenai sexual compliance hanya menyajikan data persentase mengenai sexual compliance, sehingga belum ada penelitian yang menggambarkan sexual compliance secara mendalam. Berdasarkan hal tersebut, maka dilakukan penelitian mengenai "Gambaran Sexual Compliance pada Remaja Perempuan yang Melakukan Perilaku Seksual Pranikah", dengan tujuan untuk memberikan gambaran mengenai sexual compliance secara mendalam yang dialami oleh remaja perempuan yang melakukan perilaku seksual pranikah.

\section{Metode Penelitian}

Penelitian ini menggunakan metode kualitiatif karena penelitian ini bertujuan untuk mengeksplorasi lebih dalam tentang perilaku sexual compliance dari remaja perempuan yang melakukan perilaku seksual pranikah dan bukan bertujuan untuk menggeneralisasikan hasilnya terhadap populasi tertentu. Hal ini sesuai dengan pernyataan Marshal dan Rossman (1995) yaitu penelitian kualitatif adalah suatu proses yang mencoba untuk mendapatkan pemahaman yang lebih baik mengenai kompleksitas yang ada dalam interaksi manusia. Pendekatan yang digunakan dalam penelitian ini adalah fenomenologis. Fenomenologis adalah pendekatan yang lebih memfokuskan diri pada suatu fenomena tertentu dan bentuk dari studinya adalah untuk melihat dan memahami arti dari suatu pengalaman yang berkaitan dengan suatu fenomena (Denzin \& Lincoln, 2009).

Peneliti menentukan partisipan berdasarkan kesesuaian partisipan dengan kriteria yang telah ditentukan sebelumnya. Penelitian ini melibatkan dua orang partisipan perempuan berusia 13 hingga 21 tahun dan pernah melakukan perilaku seksual tanpa menginginkan perilaku seks tersebut.

Metode pengumpulan data yang digunakan adalah teknik wawancara. Menurut Herdiansyah (2010) wawancara adalah dialog antar dua orang atau lebih dengan sebuah tujuan untuk mengambil kesimpulan. Wawancara yang digunakan adalah semi terstruktur, dimana peneliti menggunakan bantuan pedoman wawancara untuk memudahkan dan memfokuskan pertanyaan yang diutarakan (Sugiyono, 2012). Adanya pedoman wawancara agar peneliti dapat tetap berfokus pada pertanyaan penelitian dan agar wawancara yang dilakukan tidak terkesan kaku.

Pada penelitian ini, analisis data dilakukan dengan menggunakan teknik inductive thematic analysis. Inductive thematic analysis adalah teknik analisa dalam penelitian kualitatif dengan menemukan pola, tema dan kategori dari sebuah data yang telah diperoleh (Patton, 2002). Dengan teknik analisa ini, peneliti menganalisa data yang diperoleh bukan berdasarkan kerangka pemikiran yang telah ada namun mampu memunculkan tema baru sesuai yang diungkapkan informan. Peneliti melakukan analisa data dengan cara melakukan verbatim terhadap hasil wawancara informan, lalu melakukan koding untuk menentukan tema-tema yang muncul pada hasil wawancara. Dari hasil koding kemudian dikelompokkan menjadi tema-tema. Beberapa tema yang telah ditemukan juga dipecah menjadi sub-tema dan sub-sub tema agar proses pembahasan dapat dilakukan dengan lebih fokus. Tema, sub-tema, dan sub-sub tema yang ditemukan kemudian dibuat kerangka berpikir dalam bentuk bagan. 
Peneliti melakukan validitas penelitian untuk mengemukakan pembuktian terkait dengan penelitian yang dilakukan. Peneliti melakukan validitas komunikatif serta validitas argumentatif. Validitas penelitian menurut Poerwandari (2007) dapat terpenuhi salah satunya dengan melakukan validitas komunikatif yaitu dengan memberikan kesempatan pada partisipan untuk mengkonfirmasi hasil penelitian dan validitas argumentatif yang merupakan validitas yang temuan dan kesimpulannya dapat diikuti dengan baik rasionalnya, serta dapat dibuktikan dengan melihat kembali ke data mentah. Peneliti melakukan validitas komunikatif dengan cara menunjukkan hasil coding kepada partisipan serta melaporkan data-data yang ditemukan peneliti terhadap informan. Partisipan memiliki kesempatan untuk mengkonfirmasi hasil penelitian dengan mengkoreksi, menambahkan, atau mengubah temuan penelitian yang dilaporkan peneliti. Pada proses ini, partisipan setuju dengan hasil penelitian peneliti. Peneliti melakukan validitas argumentatif dengan cara meminta bantuan dosen pembimbing yang lebih ahli untuk memeriksa hasil analisis sehingga dapat memastikan semua data lengkap dan dapat dipertanggung jawabkan kebenarannya.

\section{Hasil Penelitian dan Diskusi}

Penelitian mengenai "Gambaran Sexual Compliance pada Perempuan yang Melakukan Perilaku Seksual Pranikah" ini memiliki tujuan untuk mengeksplorasi secara mendalam sexual compliance yang dialami oleh perempuan yang melakukan perilaku seksual pranikah. Hasil penelitian ini juga menjadi jawaban atas pertanyaan penelitian "Bagaimana gambaran sexual compliance pada perempuan yang melakukan perilaku seksual pranikah?". Analisa data yang peneliti lakukan memunculkan beberapa pola atau tema yang memiliki kesamaan antara kedua informan. Tema-tema tersebut antara lain adalah mengenai Perilaku Seksual Pranikah, Sexual Compliance, Pemaknaan
Partisipan terhadap Aktivitas Seksual yang Tidak Diinginkan, serta Kondisi Partisipan Saat Ini.

Pada tema perilaku seksual pranikah, kedua partisipan memiliki kesamaan yaitu melakukan perilaku seksual pranikah pada usia remaja. Kedua partisipan juga merasa masyarakat memandang perilaku seksual pranikah adalah hal yang wajar, maka dari itu kedua partisipan memiliki sikap yang positif terhadap hal tersebut. Pola serupa lainnya mengenai sexual compliance dimana kedua partisipan melakukan sexual compliance karena memiliki ketakutan ditinggalkan temannya. Perasaan yang muncul setelah melakukan sexual complance merupakan perasaan yang negatif. Kesamaan lain dari kedua partisipan adalah saat ini kedua partisipan telah memaknai pengalamannya sebagai pembelajaran sehingga kedua infoman memiliki pandangan terhadap diri yang lebih baik.

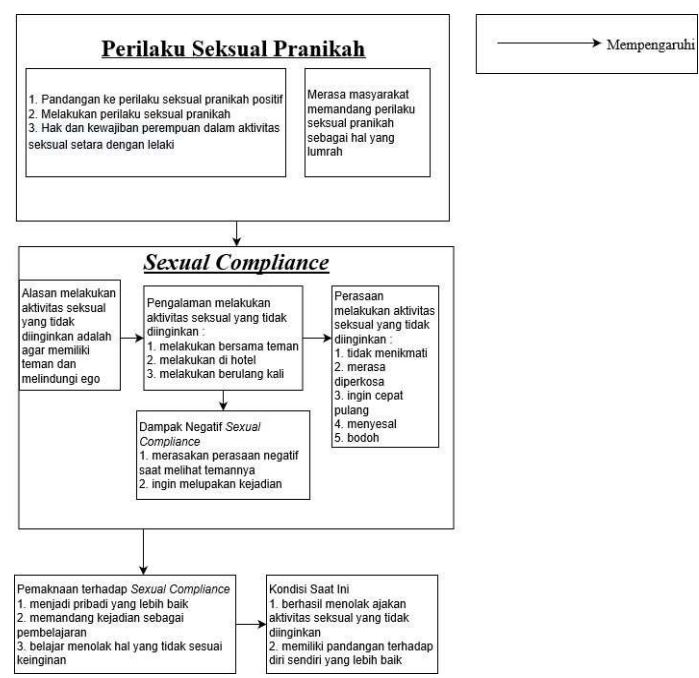

Bagan 1. Hasil Analisa Data Kedua Informan

Berdasarkan hasil analisa data kedua partisipan diatas, dapat dilihat salah satu pola yang serupa dalam tema-tema yang diidentifikasi adalah mengenai perilaku seksual pranikah. Kedua partisipan merasa pandangan masyarakat atau norma sosial kepada perilaku seksual pranikah adalah hal yang lumrah untuk dilakukan. Salah satu prinsip dalam compliance adalah validasi sosial. Prinsip validasi sosial mengatakan 
bahwa individu cenderung bersedia memenuhi permintaan untuk melakukan beberapa tindakan jika tindakan merupakan tindakan yang telah memiliki validasi dari lingkungan (Cialdini, 2006). Kedua partisipan merasa perilaku seksual pranikah di mata masyarakat adalah hal yang wajar untuk dilakukan, oleh karena itu kedua partisipan menyetujui perilaku seksual pranikah. Kedua partisipan sama-sama melakukan perilaku seksual pranikah pada umur remaja. Santrock (2011) mengatakan bahwa perilaku seksual pranikah dipengaruhi oleh perubahan pada kondisi fisik, seperti kematangan organ-organ reproduksi dan seksual, sehingga memunculkan minat seksual. Hurlock (2004) menyatakan hal yang serupa yaitu, pada masa remaja alat reproduksi manusia mulai matang dan mampu melakukan fungsi reproduksi. Sarwono (2004) juga menjelaskan bahwa salah satu faktor yang mempengaruhi perilaku seksual pranikah pada remaja merupakan meningkatnya libido seksual. Pernyataan diatas menggambarkan salah satu faktor yang mendukung kedua partisipan untuk melakukan perilaku seksual pranikah. Kedua partisipan yang sedang berada pada masa remaja mengalami perubahan pada kondisi fisik mereka, seperti kematangan alat reproduksi dan memunculkan hormonhormon seksual seperti estrogen, progesteron dan testoteron yang membuat kedua partisipan memiliki gairah seksual.

Erik Erikson (dalam Santrock, 2011) menyatakan remaja sedang dalam tahap perkembangan identity $v s$ identity confusion. Pada masa tersebut remaja sedang mencari-cari jati dirinya dengan cara mencoba hal-hal baru yang menarik baginya. Dalam mencari jati dirinya tidak jarang individu kurang memahami tanggung jawab atau konsekuensi yang akan dihadapi, salah satunya adalah perilaku seks pranikah. Teori tahap perkembangan dari Erik Erikson ini menggambarkan kedua partisipan yang sedang dalam transisi menuju masa dewasa, kedua partisipan merasa bingung atau gelisah tentang dirinya sendiri maupun tentang bagaimana mereka dapat diterima oleh masyarakat. Salah satu cara yang dilakukan untuk membangun jati dirinya adalah dengan mengeksplorasi hal-hal baru termasuk hal seksual. Eksplorasi inilah yang mengakibatkan kedua partisipan melakukan perilaku seksual pranikah. Rahardjo, dkk. (2017) menyatakan bahwa sikap positif terhadap perilaku seksual pranikah menjadi faktor pendorong utama dilakukannya perilaku seks pranikah. Kedua partisipan menyatakan memiliki sikap positif pada perilaku seksual pranikah, hal itu menjadi faktor pendorong kedua partisipan dalam melakukan perilaku seksual pranikah. Penelitian lain oleh Mahmuda, Yaunin \& Lestari (2016) menyatakan bahwa ada hubungan antara sikap terhadap berbagai perilaku seksual dengan perilaku seksual remaja. Sikap kedua partisipan yang menyetujui perilaku seksual pranikah menjadi faktor yang mempengaruhi kedua partisipan melakukan perilaku seksual pranikah.

Lingkungan pergaulan yang negatif memberi kesempatan individu untuk melakukan perilaku-perilaku yang melanggar norma agama, salah satunya adalah perilaku seksual pranikah. Sarwono (2011) menyatakan pergaulan yang semakin bebas merupakan faktor individu melakukan perilaku seksual pranikah. Kedua partisipan melakukan aktivitas seksual bersama temannya, hal tersebut menjadi bukti bahwa kedua partisipan berada pada lingkungan pergaulan yang negatif. Lingkungan pergaulan inilah kemudian menjadi faktor kedua partisipan melakukan perilaku seksual pranikah.

Peneliti menemukan pola lain pada kedua partisipan yaitu sexual compliance. Kedua partisipan menyetujui untuk melakukan aktivitas seksual yang tidak diinginkan ketika usia remaja. Kristanti dan Poerwandari (2018) menyatakan bahwa usia 25 tahun ke bawah menunjukkan perilaku compliance dalam berhubungan seksual lebih tinggi dibanding usia 25 tahun ke atas. Alasan kedua partisipan melakukan 
aktivitas seksual yang tidak diinginkan adalah agar memiliki teman. Kedua partisipan memiliki ketakutan akan ditinggalkan oleh temannya jika ia menolak aktivitas tersebut. Alasan kedua partisipan didukung oleh penelitian yang dilakukan oleh Shotland dan Goodstein (1992) yang menyatakan bahwa salah satu alasan perempuan melakukan aktivitas seksual yang tidak diinginkannya adalah ketakutan untuk ditinggalkan. Kedua partisipan melakukan aktivitas seksual tersebut agar tidak ditinggalkan oleh temannya, sehingga mereka tetap memiliki teman. Impett dan Peplau (2003) menjelaskan terdapat 62\% wanita yang melakukan sexual compliance karena ketakutan akan ditinggalkan. Penelitian ini juga mendukung alasan kedua partisipan dalam melakukan sexual compliance.

Kedua partisipan penelitian melakukan sexual compliance bersama teman. Salah satu prinsip dalam compliance adalah prinsip pertemanan dan rasa suka (Cialdini, 2006), prinsip tersebut menjelaskan bahwa individu akan lebih bersedia memenuhi permintaan dari teman atau orang-orang yang kita sukai daripada permintaan orang asing atau orang-orang yang tidak kita sukai. Teori ini mendukung perilaku sexual compliance yang dilakukan oleh kedua partisipan karena kedua partisipan melakukan aktivitas seksual yang tidak ia ingini bersama temannya. Kedua partisipan bersedia memenuhi permintaan temannya untuk melakukan aktivitas seksual walaupun sebenarnya kedua partisipan tidak memiliki keinginan untuk melakukan aktivitas seksual tersebut.

Kedua partisipan penelitian merasakan beberapa perasaan negatif seperti menyesal, tidak menikmati aktivitas seksual, hingga merasa seperti diperkosa. Penelitian yang dilakukan oleh Kristanti dan Poerwandari (2018) mengungkapkan bahwa muncul emosi negatif pada perempuan yang melakukan sexual compliance, salah satu emosi negatif tersebut merupakan perasaan menyesal. Sexual compliance terasosiasi dengan aktivitas seksual yang tidak nikmat atau tidak menyenangkan. (Impett, Peplau, \& Gable, 2005; O'Sullivan \& Allgeier, 1998; Vannier \& O'Sullivan, 2010). Pernyataan tersebut menggambarkan perasaan kedua partisipan mengenai aktivitas seksual yang mereka lakukan bersama temannya. Kedua partisipan tidak menikmati aktivitas seksual tersebut, bahkan kedua partisipan merasa seperti diperkosa. Kedua partisipan merasa melakukan aktivitas seksual yang tidak menyenangkan bagi mereka sendiri, walaupun aktivitas seksual tersebut dapat dipandang menyenangkan atau nikmat bagi teman kedua informan.

Penelitian yang dilakukan oleh Arata dan Burkhart (1995), menyatakan bahwa aktivitas seksual tanpa ijin sangat erat kaitannya dengan pengalaman emosi negatif. Hasil penelitian tersebut mendukung pernyataan kedua partisipan yang hingga sekarang masih menyimpan perasaan negatif karena telah melakukan aktivitas seksual tanpa ijin bersama temannya. Dampak negatif sexual compliance pada kedua partisipan masih ada dalam diri kedua informan. Hal tersebut juga dapat dilihat dari perasaan negatif kedua partisipan yang muncul ketika kedua partisipan melihat temannya.

Cohen dan Laxarus menyatakan salah satu keuntungan dari coping dalam mengatasi situasi stress adalah dapat membantu menjaga pandangan diri yang lebih positif dan mengurangi kondisi lingkungan yang negatif. Pernyataan ini sesuai dengan kondisi kedua partisipan saat ini yaitu menjadi pribadi yang lebih baik. Kedua partisipan mengatasi pengalaman negatifnya hingga memiliki pandangan terhadap diri yang lebih baik daripada dulu. Kedua partisipan juga dapat menolak ajakan untuk melakukan aktivitas seksual yang tidak diinginkan saat ini. Hal ini menggambarkan bahwa kedua partisipan dapat mengurangi kondisi lingkungan yang negatif. Kedua partisipan memiliki kontrol untuk mengurangi kondisi yang tidak ia inginkan. 
Perbedaan dari kedua infoman dapat dilihat dari kondisi partisipan saat ini. Dampak negatif yang ada pada partisipan $\mathrm{N}$ tidak mengganggu kehidupannya saat ini. Hal ini bertolak belakang dengan partisipan $\mathrm{X}$, dimana dampak negatif yang muncul pada diri partisipan $\mathrm{X}$ setelah melakukan sexual compliance hingga saat ini masih mengganggu kehidupannya. Partisipan $\mathrm{X}$ memutuskan untuk mundur sebagai partisipan penelitian karena setelah menjalani wawancara, perasaan negatif dalam diri partisipan $\mathrm{X}$ kembali dirasakan. Herman (1992) mengatakan bahwa perempuan yang menjadi korban pelecehan seksual pada saat dewasa sangat rentan terhadap konsekuensi psikologis jangka pendek dan jangka panjang. Pernyataan tersebut sejalan dengan partisipan X karena partisipan $\mathrm{X}$ mengalami konsekuesi psikologis jangka pendek dan jangka panjang. Kemunculan perasaan negatif pada partisipan $\mathrm{X}$ saat ini menunjukkan konsekuensi psikologis jangka panjang. Perbedaan kondisi partisipan $\mathrm{X}$ dan partisipan $\mathrm{N}$ juga dapat dijelaskan dari jumlah orang yang melakukan aktivitas seksual bersama informan. Menurut Yuan, Koss \& Stone (2006), perbedaan konsekuensi psikologis terkait dengan karakteristik kekerasan seksual, kondisi lingkungan, dan ketersediaan sumber dukungan sosial. Hal ini mendukung perbedaan konsekuensi psikologis yang dialami partisipan $\mathrm{X}$ dan partisipan $\mathrm{N}$, karena kondisi lingkungan kedua partisipan berbeda. Partisipan N dalam sekali aktivitas seksual melakukan bersama satu orang, berbeda dengan partisipan $\mathrm{X}$ yang dalam sekali aktivitas seksual melakukan bersama beberapa orang. Partisipan X memandang pengalamannya sebagai sesuatu yang traumatis sehingga ia ingin melupakan kejadian tersebut dengan cara memutus hubungan dengan teman-temannya. Karakteristik kekerasan seksual yang dialami oleh kedua partisipan juga berbeda, partisipan $\mathrm{N}$ tidak mendapatkan ancaman apapun untuk melakukan aktivitas seksual, sedangkan partisipan $\mathrm{X}$ mendapatkan ancaman dari teman-temannya untuk melakukan aktivitas seksual. Perbedaan karakteristik ini juga menjelaskan perbedaan konsekuensi psikologis atau dampak negatif yang dirasakan oleh kedua informan, dimana partisipan $\mathrm{N}$ sudah tidak terganggu oleh dampak negatif yang ia miliki, sedangkan partisipan $\mathrm{X}$ masih terganggu oleh dampak negatif sexual compliance.

Penelitian yang dilakukan oleh Halligan, Michael, Clark \& Ehlers (2003) menjelaskan bagaimana cara korban secara mental memproses pengalaman mereka mengenai trauma seksual berkaitan dengan konsekuensi kesehatan. Pernyataan tersebut dapat menjelaskan perbedaan kondisi partisipan $\mathrm{N}$ dan partisipan X. Partisipan N melihat pengalaman sexual compliance nya sebagai sebuah proses pembelajaran. Partisipan $\mathrm{N}$ memproses pengalamannya secara positif hingga ia dapat berada di posisi saat ini. Pengalaman sexual compliance membuat partisipan $\mathrm{N}$ menjadi sadar mengenai kesetaraan peran gender, ijin dalam aktivitas seksual hingga mindset untuk tidak melakukan aktivitas seksual bersama teman. Kondisi ini berbeda dengan partisipan $\mathrm{X}$, partisipan $\mathrm{X}$ masih memandang pengalamannya sebagai sesuatu yang negatif. Walaupun partisipan $\mathrm{X}$ mendapatkan pembelajaran dari kejadian yang ia lalui, namun perbedaan proses mental antara partisipan $\mathrm{X}$ dan partisipan $\mathrm{N}$ terlihat dari kondisi kedua partisipan saat ini. Partisipan N menjadikan pengalamannya sebagai batu pijakan untuk mengambil keputusan dan berpikir di masa depan, sedangkan partisipan $\mathrm{X}$ memilih untuk memutus segala hal yang berhubungan dengan pengalaman sexual compliance nya.

\section{Simpulan dan Saran}

Penelitian mengenai "Gambaran Sexual Compliance pada Perempuan yang Melakukan Perilaku Seksual Pranikah" ini memiliki tujuan untuk mengeksplorasi secara mendalam sexual compliance yang dialami oleh perempuan yang melakukan 
perilaku seksual pranikah. Hasil dari penelitian ini juga menjadi jawaban atas pertanyaan penelitian "Bagaimana gambaran sexual compliance pada perempuan yang melakukan perilaku seksual pranikah?”. Perilaku seksual pranikah merupakan awal dari pengalaman sexual compliance informan. Partisipan melakukan sexual compliance agar memiliki teman. Partisipan memiliki ketakutan akan ditinggalkan oleh temannya. Alasan tersebut akhirnya membuat partisipan melakukan aktivitas seksual yang tidak ia inginkan bersama temannya. Sexual compliance yang dilakukan partisipan menimbulkan sejumlah perasaan negatif dalam dirinya. Perasaan negatif itu antara lain perasaan menyesal, tidak menikmati aktivitas seksual, hingga merasa diperkosa. Namun saat ini, partisipan dapat mengatasi pengalaman negatif sexual compliancenya hingga memiliki pandangan yang lebih positif terhadap dirinya sendiri. Dengan demikian Gambaran Sexual Compliance Perempuan yang Melakukan Akivitas Seksual Pranikah terlihat erat kaitannya dengan perilaku seksual pranikah yang dilakukan partisipan sebagai jembatan pengalaman sexual compliance informan.

Keseluruhan proses penelitian ini membuat menjadi suatu pembelajaran bagi peneliti, oleh karena itu peneliti memberikan beberapa saran terkait penelitian. Salah satunya bagi partisipan yang dalam hal ini merupakan perempuan yang pernah melakukan aktivitas seksual yang tidak diinginkan, agar dapat memaknai pengalamannya sebagai sebuah pembelajaran untuk kedepannya, bukan sebuah musibah yang terjadi. Partisipan juga diharapkan untuk lebih memikirkan segala keputusan yang akan diambil sehingga dapat meminimalisir kekecewaan terhadap keputusan tersebut. Bagi peneliti selanjutnya yang ingin melanjutkan penelitian ini atau mengembangkan penelitian ini perlu memahami dan menguasai teknik wawancara serta metode penelitian kualitatif yang baik. Peneliti selanjutnya juga diharapkan agar selalu memperhatikan kenyamanan partisipan agar penelitian yang dilakukan tidak mengganggu kondisi partisipan baik dari sisi psikologis, sosial dan lainnya. Bagi masyarakat diharapkan untuk menghormati budaya Indonesia yang tidak mengijinkan aktivitas seksual pranikah, oleh karena itu masyarakat diharapkan untuk melakukan aktivitas seksual hanya setelah melalui proses pernikahan yang sah. Masyarakat juga diharapkan untuk memikirkan keputusan melakukan aktivitas seksual secara matang agar meminimalisir penyesalan kedepannya. Masyarakat juga diharapkan untuk mengedukasi diri mengenai seks sebelum melakukan aktivitas seksual itu sendiri. Bagi seluruh perempuan diharapkan untuk mengetahui bahwa aktivitas seksual memiliki posisi yang setara untuk lelaki dan wanita. Perempuan juga diharapkan untuk mengetahui bahwa setiap orang dapat menolak aktivitas seksual jika tidak menginginkannya. Perempuan diharapkan untuk berani dan tegas untuk menolak aktivitas seksual yang tidak diinginkannya sehingga tidak ada penyesalan yang terjadi ke depannya.

\section{Daftar Pustaka}

Arata, C. M. \& Burkhart, B. R. (1995). Post-traumatic stress disorder among college student victims of acquaintaice assault. Journal of Psychology and Human Sexuality, 8, 79-92

Cialdini, R. B. (2006). Influence: The psychology of persuasion. New York: Collins Business.

Cohen, F. \& Lazarus, R. S. (1979). Coping with the stresses of illness. In Adler (Eds.) Health Psychology. San Francisco: Jossey-Bass

Denzin, N. K. \& Lincoln, Y. S. (2009). Handbook of qualitative research. Yogyakarta : Pustaka Pelajar.

French, B. H. \& Neville, H. A. (2016). What is nonconsensual sex? Young women identify sources of coerced 
sex. Violence Against Women, 4(12), 1-27.

Halligan, S. L., Michael, T., Clark, D. M., \& Ehlers, A. (2003). Posttraumatic stress disorder following assault: The role of cognitive processing, trauma memory, and appraisals. Journal of Consulting and Clinical Psychology, 71(3) DOI: $\quad 10.1037 / 0022$ 006X.71.3.419

Herdiansyah, H. (2010). Metode penelitian kualitatif. Jakarta: Salemba Humanika

Herman, J. L. (1992). Trauma and recovery. New York: Basic Books

Hurlock, E. B. (2004). Psikologi perkembangan. Jakarta: PT Gelora Aksara Pratama.

Impett, E. A. \& Peplau, L. A. (2002). Why some women consent to unwanted sex with a dating partner: insights from attachment theory. Psychology of Women Quarterly, 26, 360-370.

Impett, E. A. \& Peplau, L. A. (2003). Sexual compliance: Gender, motivational, and relationship perspectives. The Journal of Sex Research, 40(1), 87-100. http://dx.doi.org/10.1080/002244903 09552169

Impett, E. A. \& Peplau, L. A., Gable, S. L. (2005). Approach and avoidance sexual motives: Implications for personal and interpersonal well being. Personal Relationships, 12, 465-

Katz, J. \& Tirone, V. (2009). Women's sexual compliance with male dating partners: Associations with investment in ideal womanhood and romantic well-being. Sex Roles, 60, 347-356.

Kristanti, I. \& Poerwandari, E. K. (2018). Premarital sexual compliance among urban Indonesian qomen: A descriptive study. Psychological Research on Urban Society, 1(1) 2637. DOI:10.7454/proust.v1i1.8

Maass, V. S. (2006). Facing the complexities of women's sexual desire. New York, NY: Springer Science + Business Media.

Mahmudah., Yaunin, D., Lestari, Y. (2016). Faktor-Faktor yang Berhubungan dengan Perilaku Seksual Remaja di Kota Padang. Jurnal Kesehatan Andalas, 5(2).

Marshal, C. \& Rossman, G. B. (1995). Designing qualitative research. USA: Sage Publication.

O’Sullivan, L. F. \& Allgeier, E. R. (1998). Feigning sexual desire: Consenting to unwanted sexual activity in heterosexual dating relationships. The Journal of Sex Research, 35(3): 234243.

Patton, M. Q. (2002). Qualitative research and evaluation methods $\left(3^{\text {rd }}\right.$ ed). Thousand Oaks, CA: Sage Publications.

Poerwandari, K. (2007). Pendekatan kualitatif untuk penelitian perilaku manusia. Depok: Perfecta

Rahardjo, W., Citra, A. F., Saputra, M., Damariyanti, M., Ayuningsih, A. M., \& Siahay, M. M. (2017). Perilaku seks pranikah pada mahasiswa: Menilik peran harga diri, komitmen hubungan, dan sikap terhadap perilaku seksual pranikah. Jurnal Psikologi, 44(2), 139-152. DOI: 10.22146/jpsi.23659

Sarwono, W. S. (2004). Psikologi remaja. Jakarta: PT Raja Grafindo Persada

Sarwono, W. S. (2011). Psikologi remaja. Jakarta: PT Raja Grafindo Persada.

Santrock, J. W. (2011). Life-span development $\left(13^{\text {th }} E d\right)$. New York, USA: McGraw-Hill.

Segarra-Echebarria, R., Fernandez-Perez, I., Gracia-Moncho, J., \& DelarzeCarillo, L. (2015). Psychosexual development and sexual dysfunctions. In M. Sáenz-Herrero. (Eds.) Psychopathology in women: Incorporating gender perspective into descriptive psychopathology. (h. 25-51). Cham: Springer International Publishing 
Setiawan, R. \& Nurhidayah, S. (2008). Pengaruh pacaran terhadap perilaku seks pranikah. Jurnal Soul, 1(2), 597.

Shotland, R. L., \& Goodstein, L. (1992). Sexual precedence reduces the perceived legitimacy of sexual refusal: An examination of attributions concerning date rape and consensual sex. Personality and Social Psychology Bulletin, 18(6), 756-764.

doi:10.1177/0146167292186012

Sugiyono. (2012). Metode penelitian kuantitatif kualitatif dan $r \& d$. Bandung: CV. Alfabeta.

Vannier, S. A. \& O'Sullivan, L. F. (2010) Sex without desire: Characteristics of occasions of sexual compliance in young adults' committed relationships. The Journal of Sex Research, 47(5), 429-439, DOI: 10.1080/00224490903132051

Viscione, E. R. (2015). An investigation of correlates to compliant sex in college students. Senior Honor Projects. Kingston, RI: University of Rhode Island.

Wilis, M. \& Gray, R. O. N. (2017). Borderline personality disorder traits and sexual compliance: A fear of abandonment manipulation. Journal of Personality and Individual Differences, 117. 216-220.

Yuan, N. P., Koss, M. P., \& Stone, M. (2006). The Psychological Consequences of Sexual Trauma. Harrisburg: National Resource Center on Domestic Violence 